\title{
Políticas e tensões estéticas: uma trilogia poética ${ }^{1}$
}

\author{
Marcelo Calderari Miguel ${ }^{2}$
}

\section{Termosfera Brasil, franca estranheza}

Como um filme se apresenta a vida, memória disputada, tromba gentileza.

Entre a avidez e irreflexão, mesosférico denodo da destreza!

Reviram-se nas memórias, colossal projeto, narcotiza alguma nobreza.

Veementemente reverbera em prol do democratismo e sutileza.

A mão é ativa e protagoniza, resplendido berço, tens a genetriz delicadeza?

Nascer um grito, ecoa escondido, patenteia olhares de afoiteza.

Prontamente Brasil, firme beleza, padece algum espectro de alteza.

Mas o bem é motor e uma brava partida, revela humana fineza!

Algo vibra e pulsa, branda no peito, concretiza uma mineral pureza!

Em constitucionais remédios para 'eu' infinito, esquadrinha uma expedição antipobreza.

Logo ali veio a tona, terra de contrastes, vasta dureza e imperial aspereza.

Terra de Santa Cruz, núcleo braveza, caça o brasileiro uma estrita fortaleza.

Busca-se um elixir, aflita nação ajuíza - contracorrente a estupidez e a ardil frieza.

Garimpa país uma secular ética ainda lhe causa estranheza? Oh pátria vagareza.

\footnotetext{
${ }^{1}$ Trata-se de uma trilogia poética, e, portanto, envolve a liberdade semântica expressiva e planificada. Ademais, essa temática pauta cogitações sobre o momento social em que nos encontramos; busca-se promover uma perscrutação crítica da sociedade moderna e das tensões políticas que levam o Brasil a fracassar no combate à Covid-19.

${ }^{2}$ Especialista em Educação Científica pela Universidade Federal de Minas Gerais (UFMG); Bacharel em Administração e Bibliotecomia pela Universidade Federal do Espírito Santo (UFES). Pesquisador no Núcleo de Pesquisa 'Tabularium' Políticas de Arquivos: Observatório no Estado do Espírito Santo. ORCID 0000-0002-7876-9392 E-mail: marcelocalderari@yahoo.com.br.
} 


\section{Ikigai sentido, verde-clara unidade}

De interconexão a vida faz tecido.

Um drapeado figurativo e artístico, indumentário alarido.

Capaz de se dobrar ou de dispor circunstancial sentido. O plausível medicamento de uma vida singular, trato pensador e comedido.

Passam-se meses e mais trimestres... Pátria amada e pedestre. Ameaças golpistas e manifestações antidemocráticas tornam-se plano mestre.

Níveis que tendem à tema virar avançam rumo à uma agenda rupestre. Assemelham-se ao que a própria biografia respeita - know-how perlustre.

Imagine que nosso Ikigai sentido faz um empreendimento colaborativo.

Com finalidade e recursos cumulativos, avoca algo planejado e cativo.

Embarca circunstancial visão. Surge a amarelo-esverdeada missão e valor taxativo. Ergue-se um programa estratégico, tático e operacional, índices de inflação motriz e proativo.

Reagir faz-se necessário! Às vezes os planejamentos deslancham a vida. Outras vezes, nossa trajetória se perde em tantos devaneios, a real luta é impávida. Torga nossa sina, sem saber que rumo tomar. Reagir é preciso, nau locomovida! Sendo duzentos e dez milhões por esses brasis, a jornada é rebater a prática etnocida. 


\section{Quebrante-se! Ergue a décima quinta letra do grego alfabeto}

Feneci já para muitos.

Aborrece o morticínio.

Covid, rol cadavérico!

Velozmente chacinava.

E sofria eu, não morto.

Terrificado no sistema:

vis-à-vis, gota pandêmica.

(Desfilam por aí, alienados do poder, nada messiânico movimento)

Presentemente, oro: Oh meu Padim Ciço, milagreiro santo, mudai a sanguinária política, livrai-nos das mãos e ações pouco ungidas.

Emane a ressurreição, ainda vivos morremos, diante o desmazelo.

Se hasteia nova estirpe viral. Todavia, arrazoei, tudo irá se aliviar.

Que impacto temos.

Variante momento?

Política mascarada.

Tensas amarras cria.

Até atropelos satura.

Conspurcado satélite!

Pindorama e embuste.

Mas, o que é a saúde?

Tão pouco a consente.

Ecoa câmbios, à pressa.

Vir-a-ser erude, vacine. 